\title{
A calorimetric study of the thermal denaturation of whey proteins in simulated milk ultrafiltrate
}

\author{
BY M. RÜEGG, URSULA MOOR AND B. BLANC \\ Federal Dairy Research Institute, 3097 Liebefeld, \\ Bern, Switzerland
}

(Received 8 January 1977)

Summary. Differential scanning calorimetry (DSC) was used to study thermal transitions of the following whey proteins and enzymes in milk ultrafiltrate solution: $\beta$-lactoglobulin, $\alpha$-lactalbumin, serum albumin, $\gamma$-globulin, apo- and Fe-lactoferrin, lysozyme, ribonuclease, $\alpha$-chymotrypsin and xanthine oxidase. Denaturation enthalpies $\left(\Delta H_{D}\right)$, denaturation temperatures $\left(T_{D}\right)$ and the half width of the denaturation peaks in DSC thermograms $\left(\Delta T_{D}^{+1}\right)$ were determined and the degree of renaturation was estimated by rescanning previously denatured samples. A fair correlation between the results obtained by DSC and other more classical methods was found in general. However, for some proteins ( $\alpha$-lactalbumin, lysozyme, ribonuclease and xanthine oxidase), which have so far been considered relatively thermostable, calorimetry reveals conformational changes starting at temperatures as low as about $45^{\circ} \mathrm{C}$. In these cases thermostability observed after heat treatment of milk should be interpreted in terms of renaturation and not of high temperatures of denaturation.

Calorimetric techniques have been found useful for studying the effect of heat on proteins in aqueous solutions (Privalov, 1974; Sturtevant, 1974). The published calorimetric investigations of protein denaturation, however, either do not include milk proteins or were not carried out in solutions resembling the natural milk medium. It was thus considered useful to examine the thermal transitions of milk proteins in milk ultrafiltrate by differential scanning calorimetry (DSC). This should give some insight into the structure and stability of proteins in milk as well as the changes in the properties of milk and milk products during heat treatment.

The present communication summarizes the results of a calorimetric investigation of the heat-induced transitions and reactions observed in milk ultrafiltrate of the following proteins: $\beta$-lactoglobulin $(\beta$-lg), $\alpha$-lactalbumin $(\alpha$-la), serum albumin, $\gamma$-globulin, lactoferrin, lysozyme, ribonuclease-A, $\alpha$-chymotrypsin and xanthine oxidase. 


\title{
Materials
}

\author{
EXPERIMENTAL
}

$\alpha$-Lactalbumin was separated by ion exchange chromatography (Thompson, 1965, cited by Gordon, 1971) from material purchased from Sigma (Sigma Chemical Co., St Louis, Mo., U.S.A.). Iron saturated bovine lactoferrin and iron free lactoferrin (apo-lactoferrin) were prepared from colostrum of Simmenthal cows according to the method of Baer, Oroz \& Blanc $(1976 a)$. Xanthine oxidase, which is available as a suspension in 3.2 M-ammonium sulphate solution (Boehringer Mannheim GmbH, West Germany), was diafiltered and concentrated with simulated milk ultrafiltrate (SMUF) (Jenness \& Koops, 1962), using a continuous Amicon ultrafiltration system and Diaflo type PM-10 membranes (Amicon Corp., Lexington, Mass., U.S.A.). The following commercial protein preparations were used without further purification: $\beta$-lg (B.D.H. Chemicals Ltd, Poole, Dorset, England), bovine serum albumin (Serva Feinbiochemica, Heidelberg, West Germany), lysozyme (Sigma), ribonuclease-A (Sigma), $\alpha$-chymotrypsin (Sigma), and bovine serum $\gamma$-globulin (Serva).

Calorimetric standards used were: indium, potassium chromate (Perkin Elmer, Norwalk, Conn., U.S.A.), naphthalene (T. Schuchardt, GmbH, München, West Germany; $99.99 \%$ purity) and benzoic acid (E. Merck, Darmstadt, West Germany; $\mathbf{9 9 . 9 8} \%$ purity).

\section{Solutions}

In preliminary experiments milk ultrafiltrate prepared with a Sartorius type SM 115.39.100 membrane (Sartorius, Göttingen, West Germany) was used. Later it was found that indistinguishable calorimetric results were obtained using SMUF, i.e. a salt solution according to Jenness \& Koops (1962) which has the following composition (mmol. $\mathrm{1}^{-1}$ ): $\mathrm{Na}, 18 \cdot 3 ; \mathrm{K}, 39 \cdot 4 ; \mathrm{Ca}, 9 \cdot 0 ; \mathrm{Mg}, 3.2 ; \mathrm{Cl}, 32.4$; phosphate, 11.6 ; citrate, $9 \cdot 6$; sulphate, 1.0 ; carbonate, $2 \cdot 2$; lactose, $146 \cdot 1$. The measurements were therefore made using SMUF. The $\mathrm{pH}$ of this salt solution was $6 \cdot 6$, its osmolarity $250 \pm 2$ mosm and electric conductivity at $20^{\circ} \mathrm{C} 0.494 \pm 0.003 \mathrm{~S} \mathrm{~m}^{-1}$. The $\mathrm{pH}$ of the solution was adjusted to $6 \cdot 7 \pm 0.1$ after dissolution of the proteins, $0.1 \mathrm{M}-\mathrm{KOH}$ or $\mathrm{HCl}$ being used for this purpose. The final solutions were passed through filters of $0.45 \mu \mathrm{m}$ pore width (Millipore Corp., Bedford, Mass., U.S.A.) to remove undissolved and denatured material. A small decrease of $\mathrm{pH}$ was observed when SMUF was heated alone. At $80^{\circ} \mathrm{C}$, for example, a $\mathrm{pH}$ of 6.42 was measured compared to 6.66 at $20^{\circ} \mathrm{C}$.

Protein concentrations ranged from 3-9\% and were determined by measuring the absorbance of suitably diluted samples in $0.1 \mathrm{M}$-phosphate buffer, $\mathrm{pH} 6.9$, with a Zeiss PMQ-II spectrophotometer (Carl Zeiss, Oberkochen, West Germany). The following optical factors $\left(E_{1}^{1} \mathrm{~cm}\right)$ and mol. wts were used: $\beta$-lg, $9 \cdot 3$ at $278 \mathrm{~nm}, 18422$ (McKenzie, 1971); $\alpha$-la, 20.6 at $280 \mathrm{~nm}$ (Quarfoth \& Jenness, 1975), 14176 (Brew, Vanaman \& Hill, 1967, corrected by Gordon, 1971); bovine serum albumin, 6.67 at $279 \mathrm{~nm}$ (Aoki et al. 1973), 66000 (Spahr \& Edsall, 1964); lactoferrin, 12.7 (apo form) and 15.7 (Fe saturated form) at $280 \mathrm{~nm}$ (Brown \& Parry, 1974), 93000 (Weiner \& Szuchet, 1975); ribonuclease-A, 7.38 at $278 \mathrm{~nm}$ (Scott \& Scheraga, 1963), 13683 (Hirs, Moore \& Stein, 1956); lysozyme, 26.3 at $281 \mathrm{~nm}, 14400$ (Sophianopoulos et al. 
1962); $\alpha$ chymotrypsin, 20.3 at $280 \mathrm{~nm}$ (Aune \& Timasheff, 1971), 25200 (Privalov \& Khechinashvili, 1974); $\gamma$-globulin, 13.5 at $275 \mathrm{~nm}, 156000$ (Sober, 1968). $\gamma$-Globulin contains various types of immunoglobulins (Ig), e.g. IgG, IgM and IgA (Alais \& Blanc, 1975). Because IgM and IgA resemble polymers of the basic IgG molecule, the approximate mol. wt of $\operatorname{IgG}(156000)$ was assumed for $\gamma$-globulin. Extinction coefficients for $\beta$-lg and $\gamma$-globulin were determined in our laboratory. They are based on dry weight determinations. A mol. wt of 275000 (Hart et al. 1970) was assumed for xanthine oxidase and its concentration determined by a modified FolinCiocalteu method (Bailey, 1967), using bovine serum albumin as a reference (Behringwerke, Marburg Lahn, West Germany).

\section{Calorimetry}

For calorimetric measurements, samples of $15 \mu \mathrm{l}$ were sealed in aluminium pans (Perkins Elmer volatile sample pans) and weighed. Thermograms (plots of heat flow as a function of temperature) in the temperature range of about $20-110^{\circ} \mathrm{C}$ were recorded on a Perkin Elmer model DSC-2 differential scanning calorimeter, equipped with the manufacturer's refrigeration accessories (Perkin Elmer, Intracooler II). The heat capacity of the reference cell was balanced using $15 \mu$ l SMUF solution. Leakage of the pans was checked before the DSC scans on an electronic microbalance (Mettler ME-22, Mettler Instruments A.G., Greifensee, Switzerland). It was readily detected by a continuous weight loss.

To determine enthalpy changes accompanying the thermal transitions samples were heated at a rate of $10^{\circ} \mathrm{C} / \mathrm{min}$ and the areas under the endotherms measured with a planimeter. The baselines were drawn as straight lines from the predenaturational to the postdenaturational DSC curve. This method of baseline construction was considered a sufficient approximation because the baseline shift due to the difference between heat capacity of denatured and native proteins was small compared to the heat effect accompanying the thermal transitions (Brennan, Miller \& Whitwell, 1969).

The predenaturational changes which have been observed by Privalov, Khechinashvili \& Atanasov (1971) to occur before the effective thermal transitions have not been considered in this study. These predenaturational processes are not accompanied by sharp changes of physical parameters. Only gradual increase of heat capacity takes place with the rise in temperature.

Different programming rates were used to determine the temperature of maximum heat absorption in thermograms, commonly referred to as temperature of denaturation $\left(T_{D}\right)$ or temperature of transition (Privalov, 1974; Sturtevant, 1974). This denaturation temperature is a function of heating rate either if the rate of the transition involved is comparable to the scan rate or if the process under study is irreversible (Donovan \& Ross, 1973). Therefore, DSC measurements for $T_{D}$ determinations were made using scan rates of $10,5,2.5$ and $1.25^{\circ} \mathrm{C} / \mathrm{min}$ and the temperatures of maximum heat absorption plotted as a function of heating rate. $T_{D}$ was then estimated by extrapolation to a rate of $0{ }^{\circ} \mathrm{C} / \mathrm{min}$. The symbol $T_{D}^{\circ}$ is used in this paper for the extrapolated values of temperature of denaturation.

To estimate renaturation of the proteins after thermal treatments, previously denatured samples were cooled in the calorimeter cell at a rate of $5^{\circ} \mathrm{C} / \mathrm{min}$ to $20^{\circ} \mathrm{C}$ 

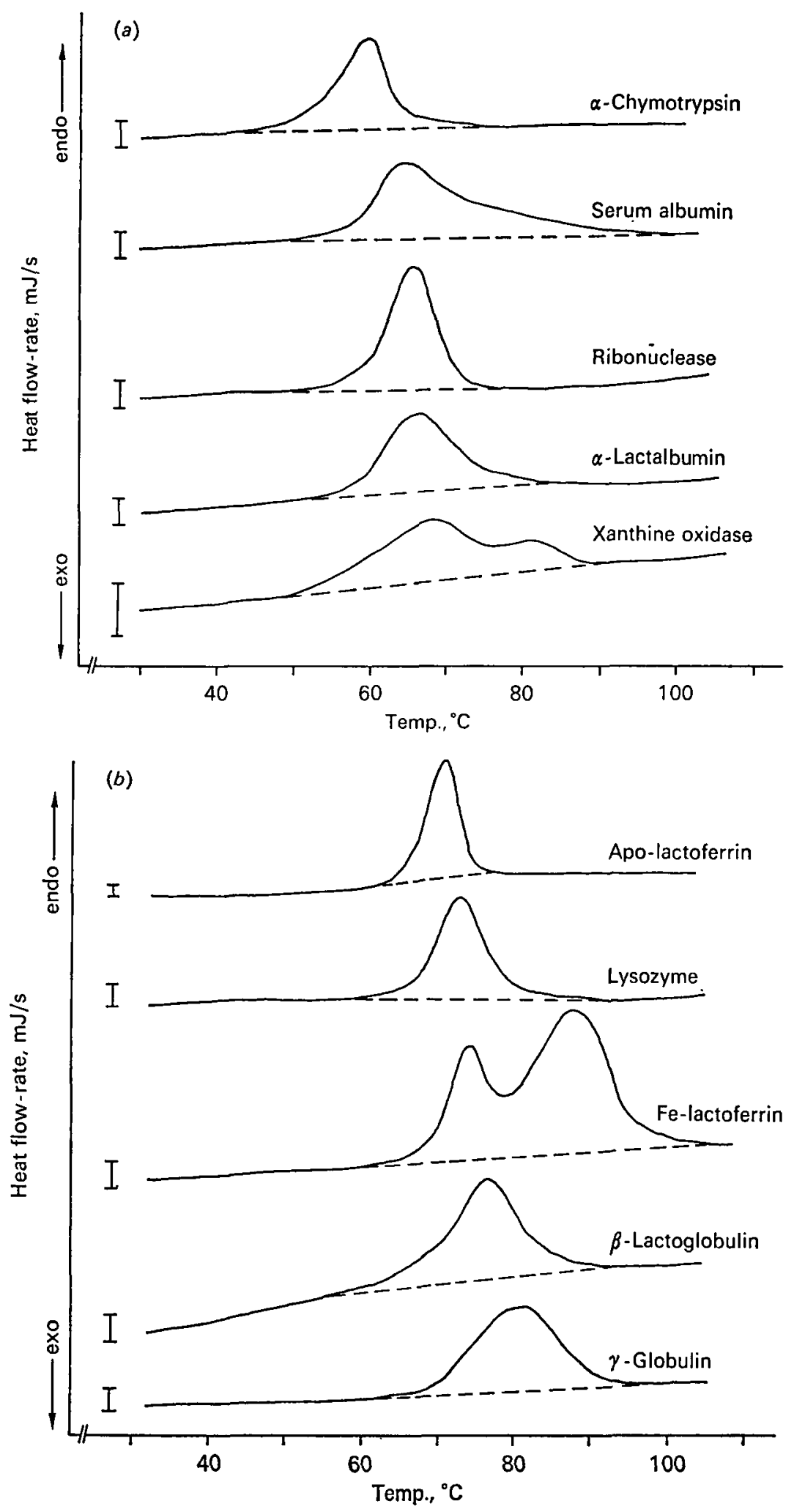

Fig. 1(a) and (b). For legend see opposite. 
Table 1. Thermodynamic parameters of heat denaturation of whey proteins in simulated milk ultrafiltrate

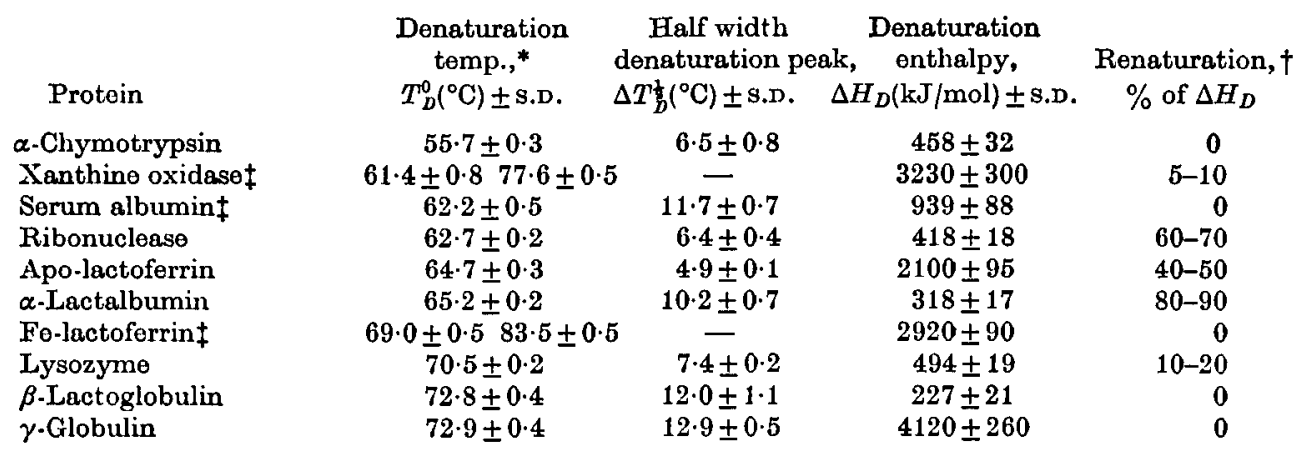

* Extrapolated values for heating rate $0^{\circ} \mathrm{C} / \mathrm{min}$ (see Fig. 2).

$\dagger$ Estimated from differontial scanning calorimetry thermograms of samples which have been denatured, cooled at a rate of $5^{\circ} \mathrm{C} / \mathrm{min}$ and rescanned.

$\ddagger$ Overlapping peaks (see Fig. 1); $\Delta H_{D}$ calculated from total area of unresolved peaks.

s.D., standard deviation.

and rescanned. The ratio of the peak areas was then taken as a measure of the extent of renaturation.

\section{RESULTS AND DISCUSSION}

Fig. $1(a)$ and $(b)$ show denaturation thermograms of the various whey proteins studied. They are ranked in the order of increasing $T_{D}$ at a heating rate of $10^{\circ} \mathrm{C} / \mathrm{min}$. The position of the denaturation peaks and, to a certain extent, the shape of these endotherms are affected by the heating rate. Fig. 2 shows the dependence of the denaturation temperatures on heating rate. A strong dependence of $T_{D}$ on heating rate indicates an irreversible process or a rate of reaction which is comparable to the scan rate. In Fig. 2, the solid lines correspond to the best fit of second-order polynomials. The temperatures of denaturation obtained by extrapolation to a scan rate of $0{ }^{\circ} \mathrm{C} / \mathrm{min}$ are included in Table 1 . This table summarizes thermodynamic parameters of the thermal transitions observed for the various whey proteins and enzymes by calorimetry. As in Fig. 1, the proteins are ranked in the order of increasing temperatures of denaturation.

For the proteins showing renaturation the van't Hoff enthalpy of denaturation $\left(\Delta H_{v H}\right)$ was estimated using the formula $\Delta H_{v H}=4 R T_{D}^{2} / \Delta T_{D}^{1}$, where $R$ is the gas constant, $T_{D}$ the midpoint of the thermal transition and $\Delta T_{D}^{\frac{1}{2}}$ the half width of the

Fig. 1. (a) and (b) Thermal denaturation of whey proteins in simulated milk ultrafiltrate. Differential scanning calorimetry thermograms of $15 \mu \mathrm{l}$ samples recorded at a heating rate of $10^{\circ} \mathrm{C} / \mathrm{min}$. Protein concentrations (\%) are: $\alpha$-chymotrypsin, 5.36 ; bovine serum albumin, 7.72; ribonuclease, 4.14 ; $\alpha$-lactalbumin, 6.18 ; xanthine oxidese, $5 \cdot 64$; apo-lactoferrin, 9.60 ; lysozyme, $7 \cdot 14 ;$ Fe-lactoferrin, $9.83 ; \beta$-lactoglobulin, $6.24 ; \gamma$-globulin, 6.33 . Endo and exo indicate the directions of endothermic and exothermic transitions. The bars represent a heat flow of $0.1 \mathrm{~mJ} / \mathrm{s}$. 


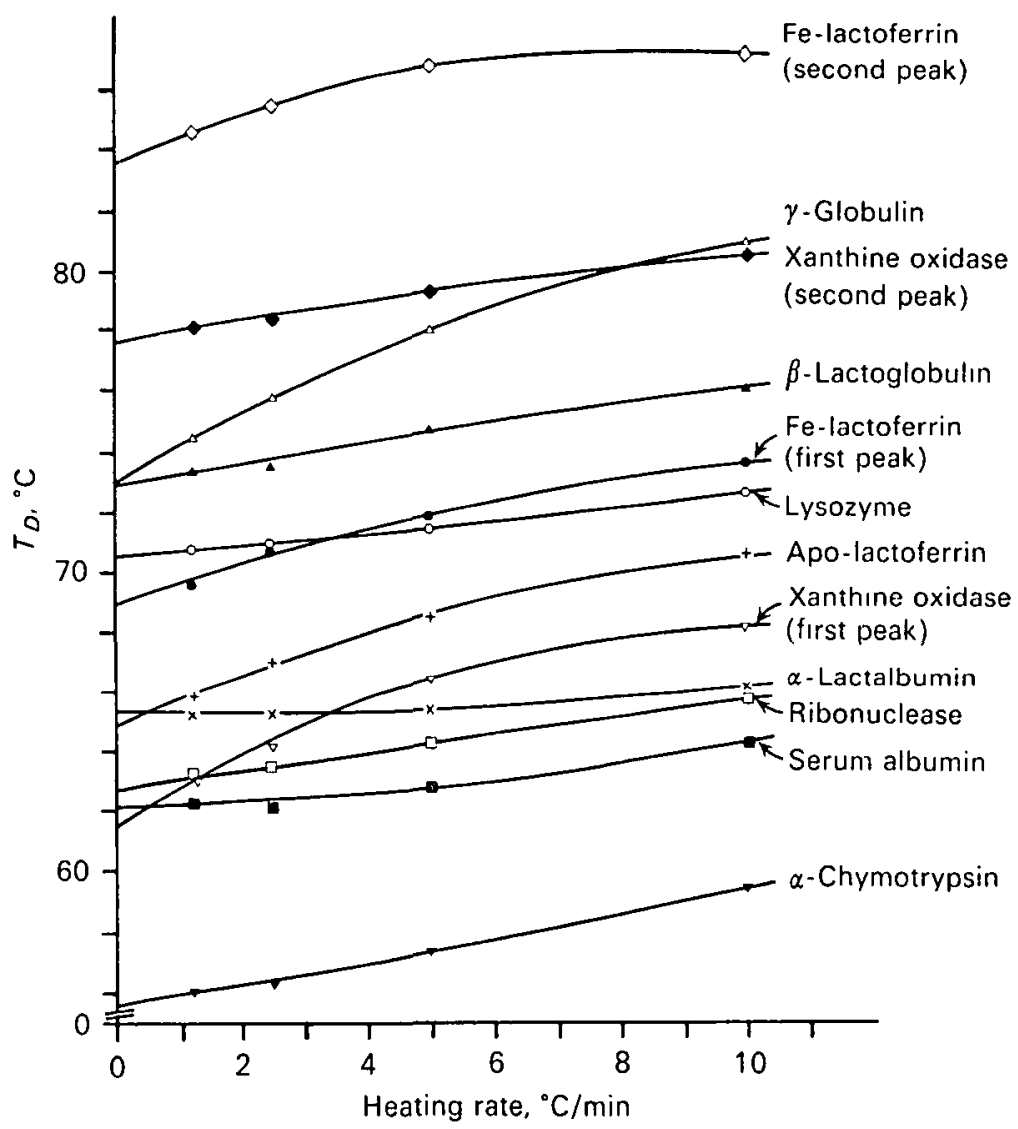

Fig. 2. Dependence of denaturation temperature $\left(T_{D}\right)$ of various whey proteins in simulated milk ultrafiltrate upon heating rate. $T_{D}$ values are temperatures of maximum deflection in differential scanning calorimotry thermograms.

heat absorption peak (Privalov et al. 1971). This approximate formula is derived from the van't Hoff equation and is valid for reversible 2-state processes only. Therefore, comparison of the enthalpy change estimated from the sharpness of the transition $\left(\Delta H_{v H}\right)$ and the heat effect determined from the peak area $\left(\Delta H_{D}\right)$ may be used as a criterion for a 2-state case, i.e. a transition involving only one initial and one final state (Privalov, 1974; Sturtevant, 1974). A lack of correspondence between $\Delta H_{v H}$ and $\Delta H_{D}$ indicates decreased cooperativity due to the presence of intermediates or to intermolecular association (Brandts, 1969).

\section{$\beta$-Lactoglobulin}

Thermograms of $\beta$-lg in SMUF reveal a single and almost symmetrical denaturation peak, similar to that observed when pure water was used as solvent (Rüegg, Moor \& Blanc, 1975). When compared to the other proteins studied, the dependence of $T_{D}$ and $\Delta T_{D}^{1}$ on $\mathrm{pH}$ was most pronounced for $\beta$-lg. However, there was no significant variation of the heat of denaturation in the $\mathrm{pH}$ range tested $(\mathrm{pH}$ 6.4-7.3). Fig. 3 shows denaturation thermograms of $\beta$ - $\lg$ in SMUF at 3 different $\mathrm{pH}$ values. Corresponding mean $T_{D}$ and $\Delta T_{D}^{\mathbf{b}}$ values are reported in Table 2. $\beta$-Lactoglobulin 


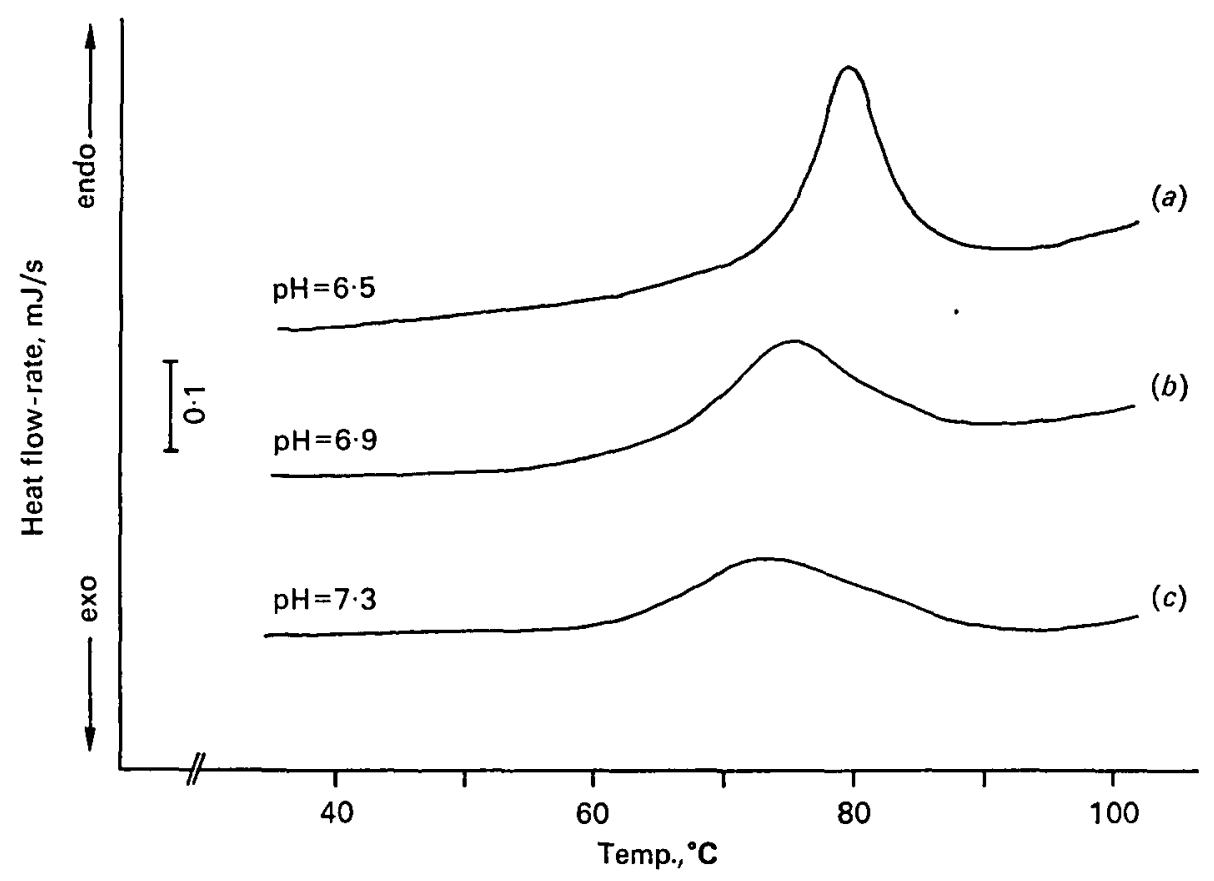

Fig. 3. pH dependence of thermodenaturation of $\beta$-lactoglobulin in simulated milk ultrafiltrate. Differential scanning calorimetry thermograms of $15 \mu \mathrm{l}$ samples recorded at a heating rate of $10^{\circ} \mathrm{C} / \mathrm{min}$. Protoin concentrations $(\%)$ are: $(a), 4 \cdot 41 ;(b), 5 \cdot 36 ;(c), 4 \cdot 55$.

Table 2. Effect of $p H$ on heat denaturation of $\beta$-lactoglobulin in simulated milk ultrafiltrate. Differential scanning calorimetry data obtained at a heating rate of $10^{\circ} \mathrm{C} / \mathrm{min}$.

$\begin{array}{ccc}\text { pH } & \begin{array}{c}\text { Denaturation } \\ \text { temp., }\end{array} & \begin{array}{c}\text { Half width of } \\ \text { denaturation peak, } \\ T_{D}\left({ }^{\circ} \mathrm{C}\right) \pm \text { S.D. }\end{array} \\ 6.46 & 79 \cdot 9 \pm 0.5 & \Delta T^{+}\left({ }^{\circ} \mathrm{C}\right) \pm \text { S.D. } \\ 6.87 & 76 \cdot 1 \pm 0.6 & 6 \cdot 6 \pm 0 \cdot 4 \\ 7.25 & 74 \cdot 4 \pm 0.4 & 12 \cdot 0 \pm 1 \cdot 1 \\ & \text { S.D., standard deviation. } & 15 \cdot 6 \pm 1.2\end{array}$

is known to undergo irreversible thermodenaturation due to aggregation involving sulphur groups, followed by nonspecific aggregation (Sawyer, 1968; McKenzie, 1971). The complex pathway for the heat denaturation of this protein might explain the strong dependence of the denaturation temperature and sharpness of the denaturation peak on heating rate and $\mathrm{pH}$.

\section{$\alpha$-Lactalbumin}

Among the proteins tested, $\alpha$-la showed the greatest extent of renaturation: 80 $90 \%$ reversibility was observed at protein concentrations of $3-9 \%$ and for the particular experimental procedure used in this study. This high degree of renaturation presumably accounts for the fact that $\alpha$-la has been considered as the most resistant of all the whey proteins (Shukla, 1973). The midpoint of the thermal transition is 
significantly lower than that for various other whey proteins including $\beta$-lg, lactoferrin, lysozyme and $\gamma$-globulin and remains independent of heating rate up to a rate of about $5{ }^{\circ} \mathrm{C} / \mathrm{min}$.

The enthalpy of denaturation of $\alpha$-la in milk ultrafiltrate, $\Delta H_{D}=318 \mathrm{~kJ} / \mathrm{mol}$, is higher than that observed in $\mathrm{pH} 6.9$ phosphate buffer solution, $\Delta H_{D}=272 \mathrm{~kJ} / \mathrm{mol}$ (Rüegg et al. 1977). This suggests a conformation stabilizing effect of lactose, citrate or $\mathrm{Ca}^{2+}$.

The van't Hoff enthalpy of denaturation, $\Delta H_{v H}=376 \mathrm{~kJ} / \mathrm{mol}$, as estimated from the sharpness $\left(\Delta T_{D}^{\frac{1}{2}}\right)$ and position $\left(T_{D}\right)$ of the denaturation peak, is higher than the corresponding calorimetric $\Delta H_{D}$. This indicates that the thermal transition observed is not a simple 2-state process. Similar conclusions were drawn by Baer, Oroz \& Blanc $(1976 b)$ from their immunochemical measurements of the heat denaturation of $\alpha$-la. Intermolecular interactions may explain in part the deviation from the 2state case (Shukla, 1973).

\section{Bovine serum albumin}

The thermal analysis of serum albumin reveals fairly complex thermograms with several overlapping endothermic peaks over a wide temperature range. Privalov \& Monaselidze (1963), when studying human serum albumin in buffer solution of $\mathrm{pH} 7$, obtained 3 denaturation peaks at about 55,67 and $75^{\circ} \mathrm{C}$. They calculated a total heat of denaturation of $883 \mathrm{~kJ} / \mathrm{mol}$. This value may be compared to that obtained for bovine serum albumin in SMUF, $\Delta H_{D}=939 \pm 88 \mathrm{~kJ} / \mathrm{mol}$. However, the temperature interval and peak shapes are different for the albumins in buffer solution and milk ultrafiltrate.

The complex behaviour of serum albumins upon heating has been explained in terms of microheterogeneity and formation of heat-stable intermediate forms due to SH-SS exchange reactions (Aoki et al. 1973; Privalov \& Monaselidze, 1963).

\section{$\gamma$-Globulin}

Despite the biochemical heterogeneity of $\gamma$-globulin, denaturation thermograms reveal a single and symmetrical peak in a relatively small temperature interval $\left(\Delta T_{D}^{\frac{1}{D}}=12.9^{\circ} \mathrm{C}\right)$. The temperature of denaturation is strongly dependent on heating rate. A difference of about $8{ }^{\circ} \mathrm{C}$ is observed for $T_{D}$ at a heating rate of $10^{\circ} \mathrm{C} / \mathrm{min}$ and $T_{D}^{\circ}$ at a rate of $0^{\circ} \mathrm{C} / \mathrm{min}$.

The high temperature of denaturation observed in thermograms is consistent with the well known heat resistance of immunoglobulins. For example, when immunsera are heated at temperatures as high as $62^{\circ} \mathrm{C}$ for up to $3 \mathrm{~min}$, the antibody activity of the immunoglobulins seems not to be affected (Kwapinski, 1972).

\section{Lactoferrin}

Whereas apo-lactoferrin exhibits only one denaturation peak with a midpoint around $65^{\circ} \mathrm{C}$, iron-saturated lactoferrin shows a complex denaturation thermoprofile with maxima at 69 and $83^{\circ} \mathrm{C}$. The binding of iron to lactoferrin not only shifts thermal transitions to higher temperatures but also increases the enthalpy of denaturation from about $2100 \mathrm{~kJ} / \mathrm{mol}$ to approximately $2900 \mathrm{~kJ} / \mathrm{mol}$. A certain contribution to the increase in enthalpy of denaturation might be attributed to the 


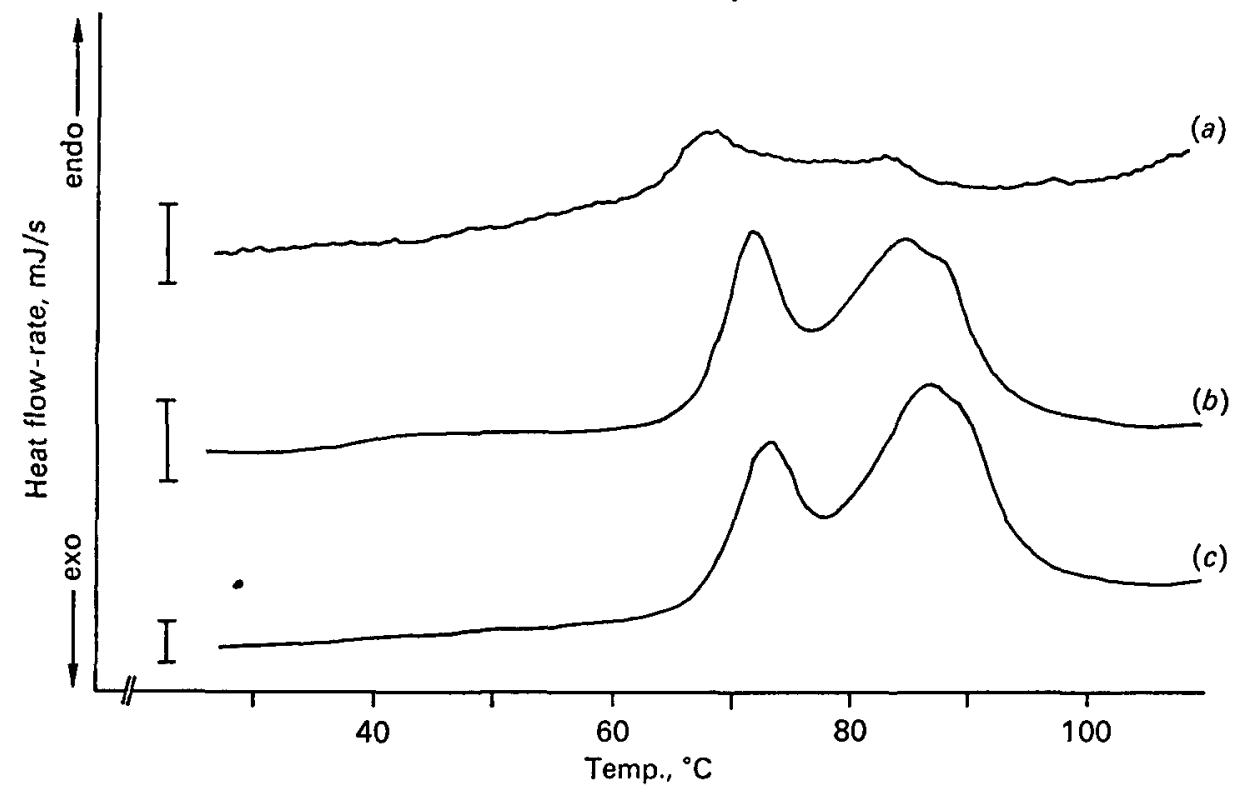

Fig. 4. Effect of heating rate on differential scanning calorimetry thermograms of Fe-lactoferrin. Protein concentration: $9 \cdot 83 \%$; solvent: simulated milk ultrafiltrate, $\mathrm{pH}=6 \cdot 6$. Heating rates are (a), $1.25^{\circ} \mathrm{C} / \mathrm{min} ;(b), 5^{\circ} \mathrm{C} / \mathrm{min} ;(c), 10^{\circ} \mathrm{C} / \mathrm{min}$. The bars represent a heat flow of $0 \cdot 1 \mathrm{~mJ} / \mathrm{s}$.

enthalpy of binding of iron to lactoferrin, but the increase of $\Delta H_{D}$ with the rise in temperature must also be taken into account (Privalov, 1974).

It may be seen from Fig. 4 that the relative size of the endotherms observed for Fe-lactoferrin was affected by heating rate. This indicates that equilibrium conditions do not exist as iron-lactoferrin solutions are heated at high scan rates.

Donovan \& Ross (1975) and Donovan et al. (1976) when studying ovotransferrins at different $\mathrm{Fe}$ to protein ratios by DSC at heating rate $10^{\circ} \mathrm{C} / \mathrm{min}$ observed 4 endotherms at characteristic temperatures. The 4 endotherms, in the order of increasing temperature, were attributed to the apo-, 2 different monoferric- and $\mathrm{Fe}_{2}$-lactoferrin species respectively. The position of the second endotherm attributed to monoferric ovotransferrin species, $76.5^{\circ} \mathrm{C}$, and that for the $\mathrm{Fe}_{2}$-ovotransferrin, $83.5-89.5^{\circ} \mathrm{C}$, may be compared to the positions of the 2 endotherms observed in thermograms of iron-lactoferrin in SMUF, 73.6 and $87.2{ }^{\circ} \mathrm{C}$ respectively. Furthermore, the enthalpy of denaturation for $\mathrm{Fe}_{2}$-ovotransferrin, $2917 \mathrm{~kJ} / \mathrm{mol}$, agrees well with $\Delta H_{D}$ calculated from the total area of the endotherms for iron-saturated lactoferrin $(2920 \mathrm{~kJ} / \mathrm{mol})$. These analogies appear to indicate that both proteins have comparable iron binding properties and that the low temperature peak in denaturation thermograms of iron-saturated lactoferrin is due to the presence of monoferric species. Formation of iron-phosphate complexes upon heating could explain the occurrence of monoferric species in SMUF solutions of iron-saturated lactoferrin. The dependence of the relative size of the 2 peaks on heating rate as shown in Fig. 4 would be consistent with a dissociation of iron from lactoferrin during the DSC scan. 


\section{Lysozyme}

Thermodenaturation of lysozyme in $0.05-0.5 \%$ solutions at $\mathrm{pH} \mathrm{2-4.5}$ was found to be totally reversible (Privalov \& Khechinashvili, 1974). However, in milk ultrafiltrate at $\mathrm{pH} 6.7$ and at protein concentrations of $3-9 \%$, reversibility was poor. Only 10-20\% renaturation was observed for the particular thermal treatment described in the experimental section. Aggregation of denatured molecules is in many cases one of the major factors which reduces the reversibility of thermal transitions. These aggregations are, as a rule, accompanied by negative enthalpy changes and might be responsible for the small difference between the calculated van't Hoff enthalpy of denaturation, $\Delta H_{v H}=537 \mathrm{~kJ} / \mathrm{mol}$, and the calorimetric heat of denaturation, $\Delta H_{D}=494 \mathrm{~kJ} / \mathrm{mol}$, which represents the sum of the enthalpy processes over the temperature range of transition.

The calculated value for the van't Hoff enthalpy of denaturation, $537 \mathrm{~kJ} / \mathrm{mol}$, agrees well with values determined by other authors from optical measurements, $532 \mathrm{~kJ} / \mathrm{mol}$ (Takesada, Nakanishi \& Tsuboi, 1973) and $515 \mathrm{~kJ} / \mathrm{mol}$ (Delben \& Crescenzi, 1969). The latter values were determined using phosphate buffer solutions of $\mathrm{pH} 5 \cdot 6$ and $5 \cdot 37$, respectively. The agreement between the $\Delta H_{\mathrm{v} H}$ values suggests that the major components of SMUF, which are not present in phosphate buffer solutions, e.g. lactose, citrate and $\mathrm{Ca}$, do not influence the thermal transition of lysozyme.

$\alpha$-Lactalbumin is known to have a close structural similarity to lysozyme and some physical and chemical properties are analogous (Shukla, 1973). Thermal stability, however, is strikingly different for these proteins. The enthalpy of denaturation as well as the temperature of denaturation is higher for lysozyme than for $\alpha$-la. It has been suggested that $\alpha$-la has a lower number of intramolecular $H$-bonds (Takesada et al. 1973). This would explain in part the lower heat of denaturation found for $\alpha$-la.

\section{Ribonuclease}

It has been reported that this enzyme is relatively resistant to heat and is normally not destroyed by pasteurization or even ultra high temperature treatments (Alais \& Blanc, 1975; Shahani, 1966; Zittle, 1964). If one takes into account the conformational change observed by calorimetry at about $63^{\circ} \mathrm{C}$ the heat resistance of this enzyme must probably be explained by a high degree of renaturation after thermal treatments. This conclusion is supported by the results obtained from thermal measurements of the isolated enzyme in SMUF. Renaturation of 60-70\% was observed after rapid cooling and a short temperature equilibration at $20^{\circ} \mathrm{C}$.

The symmetrical denaturation peak for ribonuclease has a maximum around $63{ }^{\circ} \mathrm{C}$, a value which may be compared to that observed by other authors in water (Delben, Crescenzi \& Quadrifoglio, 1969) or NaCl solutions (Tsong et al. 1970), i.e. 60-62 ${ }^{\circ} \mathrm{C}$. Also the $\Delta H_{D}$ value of about $418 \mathrm{~kJ} / \mathrm{mol}$ found in SMUF solutions is in agreement with data obtained by DSC in the $\mathrm{pH}$ range 6-9 using water as solvent, $\Delta H_{D}=414 \mathrm{~kJ} / \mathrm{mol}$ (Delben et al. 1969). The enthalpy of denaturation reported by Tsong et al. (1970) for ribonuclease denaturation at $\mathrm{pH} 7$ in $0.2 \mathrm{~N}-\mathrm{NaCl}$ is significantly higher, i.e. $703 \mathrm{~kJ} / \mathrm{mol}$. However, this value refers to the temperature of 
transition, whereas the DSC data are average values over the temperature range of transition. It should also be considered that the DSC data were obtained using 3$5 \%$ solutions, whereas Tsong et al. (1970) used more dilute solutions. Comparison of the DSC data obtained in water (Delben et al. 1969) and in SMUF suggests that heat denaturation of ribonuclease is little affected by constituents of milk ultrafiltrate.

\section{$\alpha$-Chymotrypsin}

Heat denaturation of $\alpha$-chymotrypsin has been extensively studied by calorimetry in the $\mathrm{pH} 2-4$ range (Brown, 1971; Privalov \& Khechinashvili, 1974). In this $\mathrm{pH}$ range the thermal transition was reversible and apparently a simple 2-state process (Privalov \& Khechinashvili, 1974). In SMUF solutions, however, the heat denaturation was found to be irreversible.

A high temperature shoulder in denaturation thermograms of chymotrypsin has been observed when sucrose was present in the solvent (Cassel, 1973). A similar shoulder is observed in SMUF which contains lactose (Fig. 1). At protein concentrations higher than about $6 \%$, reproducibility of the denaturation peak shape was poor, possibly due to aggregations which are favoured at high protein concentrations and at $\mathrm{pH}$ values in the vicinity of 7 .

\section{Xanthine oxidase}

Thermograms of xanthine oxidase reveal 2 endothermic transitions with maxima at about 61 and $78{ }^{\circ} \mathrm{C}$. The relative size of the 2 endotherms did not change significantly with different heating rates. Upon reheating previously denatured samples small peaks recurred in the same position as in the first scan. This indicates that there is some renaturation of the metallo-flavoprotein.

It has been reported that xanthine oxidase in milk is moderately resistant to heat and, in contrast to other enzymes, activated after certain heat treatments (Shahani, 1966; Zittle, 1964). When comparing these findings with the conformational changes observed by calorimetry, one must consider that xanthine oxidase in milk is concentrated on the fat globule membrane and that generally, isolated and purified enzymes are more heat labile (Zittle, 1964). The observed heat stability of xanthine oxidase in milk is probably due to both renaturation and a protective effect of other milk constituents. The presence of a heat resistant xanthine oxidase activator has also been discussed (Shahani, 1966).

\section{CONCLUSIONS}

Calorimetry allows one not only to follow the heat denaturation of proteins, but also to obtain information about reversibility and, in favourable cases, the mechanism of the reactions involved in thermal transitions.

In general, a fair correlation between the results obtained by DSC and other more classical methods was found, but for some proteins ( $\alpha$-la, lysozyme, ribonuclease and xanthine oxidase), which have been considered so far as relatively thermostable, calorimetry reveals conformational changes starting at temperatures as low as about $45^{\circ} \mathrm{C}$. In these cases, thermostability must be interpreted in terms of renaturation and not of high temperatures of denaturation. 
In this study, isolated milk serum proteins have been investigated in simulated milk ultrafiltrate. When applying the results obtained to whole milk, interactions between proteins and the various milk constituents which are not present in SMUF must be considered.

We are grateful to Dr A. Baer for providing samples of lactoferrin and to Dr M. Casey for purifying the $\alpha$-la and for his linguistic assistance.

\section{REFERENCES}

Alats, C. \& Blanc, B. (1975). World Review of Nutrition and Dietetics 20, 112.

AOKI, K., Sato, K., Nagaoka, S., Kamada, M. \& Hiramatsu, K. (1973). Biochimica et Biophysica Acta $328,323$.

AUNe, K. C. \& TIMAshefF, S. N. (1971). Biochemistry 10, 1609.

Baer, A., Oroz, M. \& Blanc, B. (1976a). Milchwissenschaft 31, 649.

Baer, A., Oroz, M. \& Blanc, B. (19766). Journal of Dairy Research 43, 419.

Baney, J. L. (1967). Techniques in Protein Chemistry, 2nd ed., p. 340. Amsterdam: Elsevier Publ. Co. Brandts, J. F. (1969). In Structure and Stability of Biological Macromolecules, p. 213. (Ed. S. N. Timasheff.) New York: Marcel Dekker, Inc.

Brennan, W. P., Muler, B. \& Whitwell, J. C. (1969). Industrial and Engineering Chemistry: Fundamentals 8, 314 .

Brew, K., Vanaman, T. C. \& HmL, R. L. (1967). Journal of Biological Chemistry 242, 3747.

Brows, H. D. (1971). Journal of Agricultural and Food Chemistry 19, 669.

Brows, E. M. \& PARRY, R. M. (1974). Biochemistry 13, 4560.

Cassel, R. B. (1973). Thermal Analysis Application Study No. 5; Perkin-Elmer Corp., Norwalk, Conn., U.S.A.

Delben, F. \& Ceescenzi, V. (1969). Biochimica et Biophysica Acta 194, 615.

Delben, F., Crescenzi, V. \& Quadrifoglio, F. (1969). International Journal of Protein Research 1, 145.

Donovan, J. W., Beardslee, R. A. \& Ross, K. D. (1976). Biochemical Journal 153, 631.

Donovan, J. W. \& Ross, K. D. (1973). Biochemistry 12, 512.

Donovan, J. W. \& Ross, K. D. (1975). Journal of Biological Chemistry 250, 6026.

Gordon, W. G. (1971). In Milk Proteins 2, 338, 347. (Ed. H. A. McKenzie.) Now York: Academic Press. Hart, L. I., McGartoll, M. R., Chapman, H. R. \& BRay, R. C. (1970). Biochemical Journal $116,851$. Hirs, C. H. W., Moore, S. \& Stern, W. H. (1956). Journal of Biological Chemistry 219, 623.

Jenness, R. \& Koops, J. (1962). Netherlands Milk and Dairy Journal 16, 153.

Kwapinski, J. B. G. (1972). Methodology of Immunochemical and Imniunological Research, p. 484. Now York: Wiley-Interscience.

McKenzie, H. A. (1971). In Milk Proteins, 2, 257. (Ed. H. A. McKenzie.) New York: Academic Press.

Privalov, P. L. (1974). FEBS Letters 40, S 140.

Privalov, P. L. \& Khechinashvimi, N. N. (1974). Journal of Molecular Biology 86, 665.

Privalov, P. L., Kengchinashvili, N. N. \& Atanasov, B. P. (1971). Biopolymers 10, 1865.

Privalov, P. L. \& Monaselidze, D. R. (1963). Biofizika 8, 420.

Quarfoth, G. J. \& Jenness, R. (1975). Biachimica et Biophysica Acta 379, 476.

RüEga, M., Moor, U. \& Blanc, B. (1975). Biochimica et Biophysica Acta $400,334$.

Rüega, M., Moor, U., Lukesch, A. \& Blanc, B. (1977). In Application of Calorimetry in Life Sciences.

(Eds I. Lamprecht and B. Schaarschmidt.) Berlin: Walter de Gruyter.

SAWYER, W. H. (1968). Journal of Dairy Science 51, 323.

Scott, R. \& Scheraga, H. A. (1963). Journal, American Chemical Society 85, 3866.

ShaHANI, K. M. (1966). Journal of Dairy Science 49, 907.

SHUkLA, T. P. (1973). CRC Critical Reviews in Food Technology 3, 241.

Sorer, H. A. (Ed.) (1968). In Handbook of Biochemistry, p. C-39. Cleveland, Ohio: Chemical Rubber Co. Sophianopoulos, A. J., Rhodes, C. K., Holcomb, D. N. \& Van Holde, K. E. (1962). Journal of Biological Chemistry 237, 1107.

SPAHR, P. F. \& EdSAlL, J. T. (1964). Journal of Biological Chemistry 239, 850.

Sturtevant, J. M. (1974). Annual Review of Biophysics and Bioengineering 3, 35.

Takesada, H., Nakanishi, M. \& Tsubor, M. (1973). Journal of Molecular Biology 77, 605.

Tsong, T. Y., Hearn, R. P., Wrathall, D. P. \& Sturtevant, J. M. (1970). Biochemistry 9, 2665.

Wenner, R. E. \& SzUchet, S. (1975). Biochimica et Biophysica Acta 393, 143.

ZirTle, C. A. (1964). Journal of Dairy Science 47, 202.

\section{Printed in Great Britain}

